3. Методика «Незаконченные предложения» // Режим доступа :

http://vseodetishkax.ru/rabota-psixologa-v-detskom-sadu/34-metodiki-izucheniyaemoczionalnoj-i-lichnostnoj-sfery/548-metodika-qnezakonchennye-predlozheniyaq

4. Велиева С. В. Методика «Паровозик» // Диагностика психических состояний детей дошкольного возраста. Режим доступа : http://www.stotestov.ru

\title{
Методика работы с документами на уроках истории
}

\author{
Неустроева С.С., студентка, \\ Северо-Восточный федеральный университет, \\ 2. Якутск \\ E-mail: boxinyaa@gmail.ru
}

Научный руководитель: к.и.н., доцент Атласова С.С.

В современной системе образования на первый план выходит не обучение обучающегося предметным знаниям, а обучение способам деятельности, обеспечивающим обучающимся способность активно, самостоятельно выстраивать свой путь познания, свою жизнь. Умения и навыки исследовательского поиска необходимы каждому человеку. Развитие навыков исследования, умение самостоятельно ставить и решать исследовательские задачи, признано в настоящее время одним из приоритетных направлений современного образования.

С помощью документов реализуется принцип исследования в обучении истории, когда ученики знакомятся с их внешним видом, содержанием, структурой и т.п. Документ делает рассказ учителя живым и ярким, а выводы более убедительными. Значимость документа также в том, что он содействует конкретизации исторического материала, созданию ярких образов и картин прошлого, создает ощущение духа эпохи.

Посредством изучения документа у обучающихся формируется интерес к истории. При работе с документами у учеников активизируется процесс мышления и воображения, что способствует более плодотворному усвоению исторических знаний и развитию исторического сознания. У обучающихся вырабатываются умения самостоятельной работы: читать документы, анализировать и извлекать информацию, рассуждать, оценивать значение документов прошлого и настоящего. На уроках ученики узнают о значимости документов для исторической науки, видят в них след деятельности живших когда-то людей.

К историческим источникам относится все созданное человеком, в том числе результаты его взаимодействия с окружающей средой, а также предметы материальной культуры, обычаи, обряды, памятники письменности. В широком смысле слова памятники письменности в методике называют документами.

Классификация документов применяемых в обучении истории, значительно проще той, что принята в исторической науке. Наиболее стройную систему классификации и систематизаџии письменных источников выдвигает Л.Н. Пушкарев:

1. Картографические: а) карты, исторические планы; б) планы политические планы; 
2. Статистические: a) экономическая статистика; б) статистика народонаселения; в) политическая и культурная статистика;

3. Актовые: а) акты политические; б) акты социально-экономические; в) акты юридические;

4. Канцелярские источники: а) грамоты; б) реестры, книги, указы; в) деловая переписка;

5. Личные: а) письма; б) дневники; в) мемуары;

6. Художественные: а) очерки (корреспонденция); б) лирика, драма; в) романы, рассказы, повести;

7. Исторические: а) исторические повести; б) хронографы; в) летописи;

8. Научные: а) исторические труды; б) философско-социологические труды; в) географические описания.

Критерии отбора документов. Документ как исторический источник для урока должен:

$\checkmark \quad$ соответствовать целям и задачам обучения истории;

$\checkmark$ отражать очевидные, наиболее типичные факты и события эпохи;

$\checkmark \quad$ быть органически связанным с программным материалом;

$\checkmark$ содействовать актуализации исторических знаний, чтобы можно было бы предложить учащимся познавательные вопросы и задания;

$\checkmark \quad$ быть доступным ученикам по содержанию и объему;

$\checkmark$ содержать бытовые и сюжетные подробности, позволяющие дифференцировать обучение, конкретизировать представления учащихся о тех или иных событиях, явлениях, процессах;

$\checkmark \quad$ оказывать на них определенное эмоциональное воздействие;

$\checkmark$ обладать литературными и научными достоинствами, достаточной информативностью для развития познавательной самостоятельности и заинтересованности, совершенствования приемов умственного труда;

$\checkmark$ важно также учитывать объем документа, его стилистический язык (доступность понимания) и определенную последовательную "нить", т.е. вызвать заинтересованность учащегося.

Приемы работы с историческими документами:

•чтение и анализ;

•выписки определений понятий, основных положений, выделение главной идеи;

•комментированное чтение;

•коллективный разбор текста;

•формулирование вопросов к тексту;

-обобщение фактического и теоретического материала в целях конкретизации изучаемых общественных явлений;

•выявление различных подходов к общественно-историческому развитию;

-анализ аргументации авторов;

•нахождение разных способов решения проблем на основе сопоставления нескольких источников;

-формулирование обобщенных выводов;

•выявление причинно-следственных связей и построение логической цепи суждений; 
•составление текстовых, сравнительно-обобщающих и конкретизирующих таблиц, логических и текстовых схем, планов (развернутого, структурно-логического, тематического), тезисов, конспекта;

•подготовка сообщений, рефератов и т.д.

Источники значительно расширяют круг социальной информации, осваиваемый обучающимися, и служат основой для развития познавательной активности школьников. Дополнение рассказа учителя ярким историческим документом повышает интерес обучающихся, конкретизирует, обогащает их представления о событиях прошлого. Практика показывает, что самостоятельная работа обучающихся с источниками знаний будет более успешной, если в ее основе лежит конкретная программа действий ученика, выстроенная в соответствии с определенной дидактической задачей и содержанием учебного материала, с учетом подготовленности ученика к работе с текстам.

Целесообразно использовать систему заданий, ориентированных на три уровня познавательной деятельности. Выбор уровней определяется познавательными возможностями ученика и целями обучения.

Первый уровень - воспроизводящий. Предполагает выписки основных понятий, определений, выводов, ответы на поставленные вопросы, требующие уточнения и пересказа текста; заполнение таблицы, схемы по образцу в ходе коллективного разбора документа, ориентированного на понимание текста; составление простого плана и т.д.

Второй уровень - преобразуюший. Вопросы и задания могут включать рассказ ученика по документу, сопровождающийся анализом текста, выделением в нем основной идеи, вывода, синтезом положений источника с другим теоретическим материалом (самостоятельный отбор, группировка фактов, идей и привлечение их учеником для раскрытия изучаемой темы); составление развернутого плана, тезисов, конспекта, текстовых таблиц, схем; самостоятельную постановку вопросов к документу; подготовку рефератов, докладов и др.

Третий уровень - творческо-поисковый. На данном уровне учащимся предлагаются познавательные задания, требующие осмысления и сопоставления точек зрения мыслителей, положений нескольких документов; выявления линий сравнения изучаемых явлений и составление сравнительных таблиц, логических цепочек; применения теоретических положений документа для доказательства, аргументирования своей точки зрения, обсуждения дискуссионных проблем; посильной поисковой деятельности по сбору материала, его анализу и систематизации по определенной теме, подготовки творческих сочинений, эссе и другие.

На уроках истории в старших классах целесообразно использовать задания, ориентированные на творческо-поисковый уровень познавательной деятельности, на развитие у учащихся умений анализировать, сопоставлять тексты документов, высказывать и обосновывать собственные оценки и суждения по рассматриваемой проблеме.

Формирование познавательных умений является одной из главных целей современного школьного исторического образования. Познавательные умения выступают как средство формирования исторических знаний, личностных суждений и мотивированного отношения к прошлому, как прогнозируемый и диагностируемый результат целенаправленного обучения истории.

Основная работа должна вестись начиная с 5 класса. Учитель должен четко представлять, каким умениям и в каких классах в соответствии с познавательными 
возрастными возможностями нужно обучать школьников, при изучении каких исторических источников можно проводить это обучение.

Исторические источники играют важную роль в процессе преподавания истории в школе. Современный урок истории немыслим без документов, исторических первоисточников, произведений выдающихся историков.

Умения работать с историческими источниками

\begin{tabular}{|c|c|c|}
\hline $\begin{array}{c}\text { Познавательно - исторические } \\
\text { умения } \\
\end{array}$ & Общелогические умения & $\begin{array}{c}\text { Общеучебные } \\
\text { умения }\end{array}$ \\
\hline \multicolumn{3}{|c|}{5 - 6 классы } \\
\hline 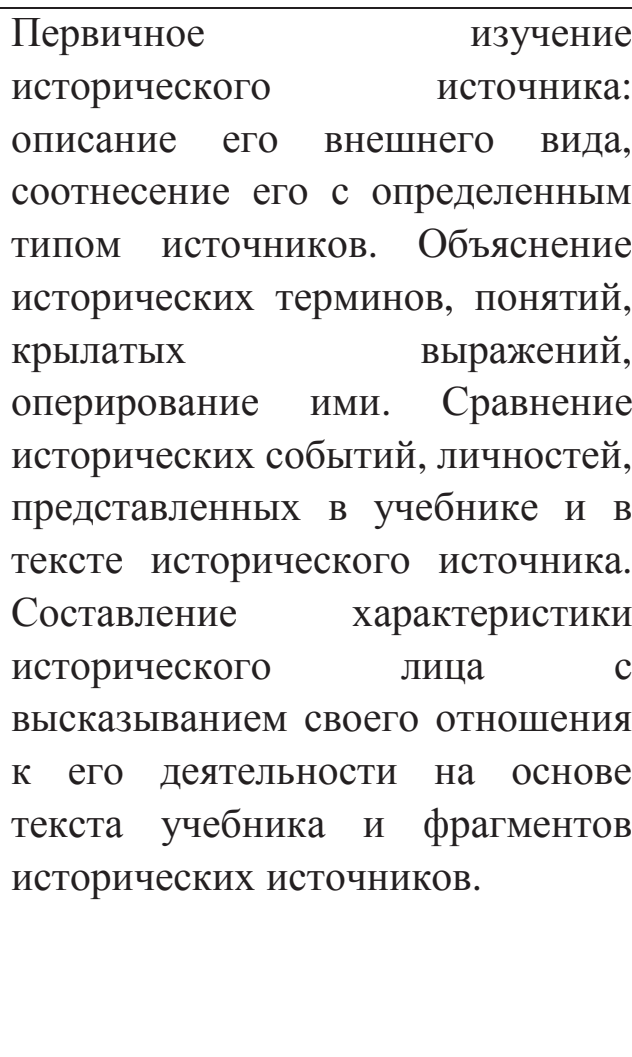 & $\begin{array}{lr}\text { Разделение } & \text { содержания } \\
\text { текста на } & \text { законченные } \\
\text { смысловые } & \text { части, } \\
\text { выделение существенных } \\
\text { признаков факта, события. } \\
\text { Обобщение извлеченного } \\
\text { из исторического } \\
\text { источника } \\
\text { Формулирование } \\
\text { несложных выводов. }\end{array}$ & $\begin{array}{l}\text { Составление } \\
\text { рассказа об } \\
\text { историческом } \\
\text { событии, деятеле на } \\
\text { основе текста } \\
\text { учебника, } \\
\text { иллюстрации, } \\
\text { фрагмента } \\
\text { исторического } \\
\text { источника. } \\
\text { Выполнение } \\
\text { творческих работ: } \\
\text { написание } \\
\text { сочинений, } \\
\text { подготовка } \\
\text { небольших } \\
\text { сообщений на основе } \\
\text { текста учебника, } \\
\text { исторических } \\
\text { источников. }\end{array}$ \\
\hline \multicolumn{3}{|c|}{7 - 9 классы } \\
\hline 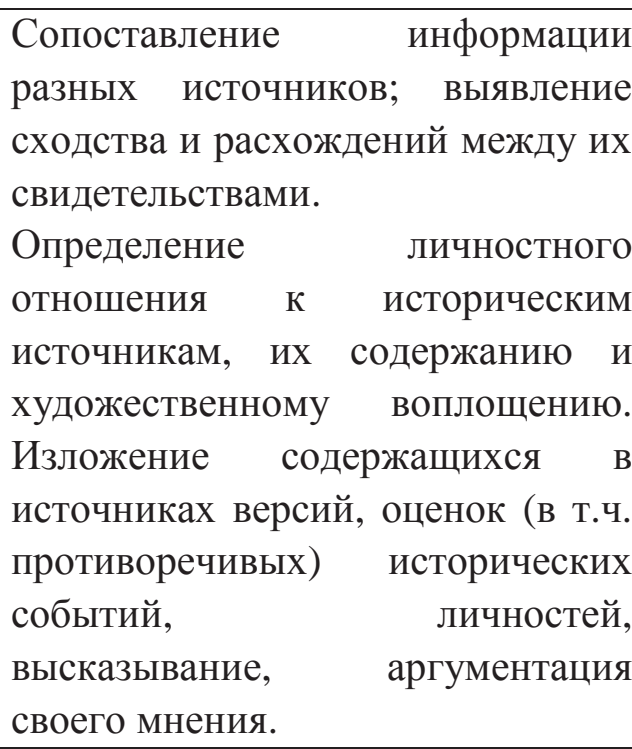 & $\begin{array}{l}\text { Обобщение исторического } \\
\text { материала, } \\
\text { формулирование выводов. }\end{array}$ & $\begin{array}{l}\text { Составление } \\
\text { развернутого плана } \\
\text { на основе изучения } \\
\text { текста учебника, } \\
\text { фрагментов } \\
\text { исторических } \\
\text { документов. }\end{array}$ \\
\hline \multicolumn{3}{|c|}{10 - 11 классы } \\
\hline
\end{tabular}




\begin{tabular}{|c|c|c|}
\hline 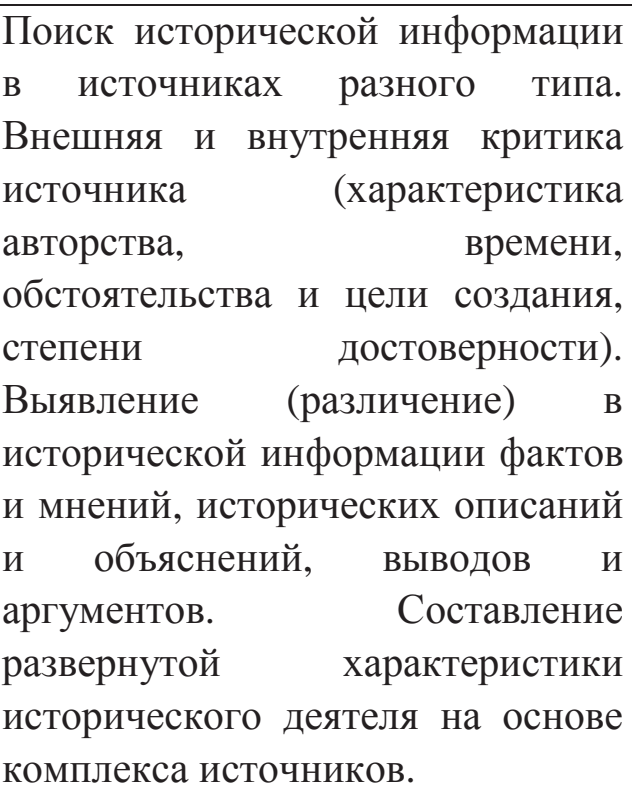 & 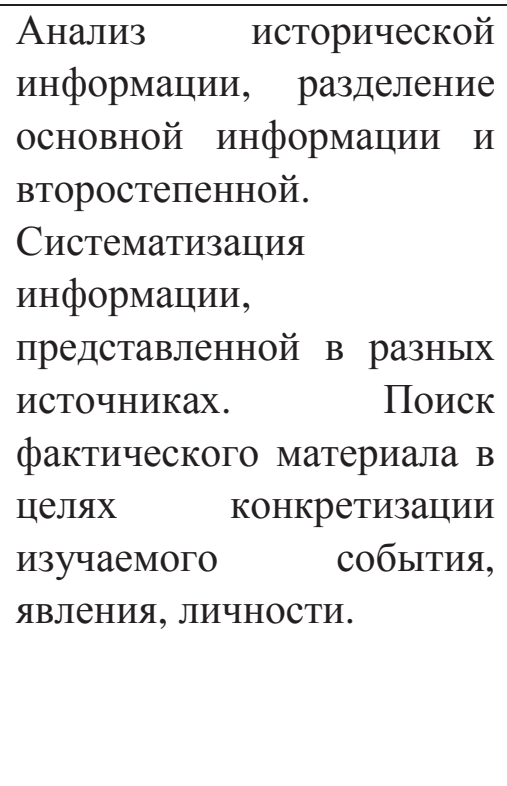 & $\begin{array}{l}\text { Составление } \\
\text { развернутого плана, } \\
\text { схемы, конспекта. } \\
\text { Написание реферата, } \\
\text { эссе, рецензии, } \\
\text { аннотации, } \\
\text { стилизации и т.д. }\end{array}$ \\
\hline
\end{tabular}

\title{
Список литературы:
}

1. Алексашкина Л.Н. Методологические основы школьного курса истории: Дис. д.п.н. М., 2012.

2. Вяземский Е.Е., Стрелова О.Ю. Методические рекомендации учителю истории. M., 2014.

\section{Игра как средство формирования эвристического мышления}

\author{
Покровский М.Д., студент, \\ Чукотский филиал Северо-Восточного \\ федерального университета, г. Анадырь \\ E-mail: mpokrovsky@hotmail.com
}

Научный руководитель: к.социол.н., доцент Горченко С.А.

В педагогике, говоря обобщенно, методы обучения распределяются между двумя полюсами - «излагающие» и «эвристические»; и то, и другое существует во множестве разновидностей, модификаций, сочетаний. Вопросы, касающиеся эвристического мышления как феномена, эвристики как метода обучения, изучены достаточно хорошо со времен Сократа, активно применяются в практике, имеют убедительное объяснение в теории. Но есть одно противоречие, которое осталось на периферии исследовательского внимания.

Массовая школа объективно «заточена» под излагающее обучение; эвристичность декларируется, имитируется, иногда применяется всерьез в порядке исключения, но реально находится за пределами действующей парадигмы отношений «ученик-учитель». Еще и потому, что, помимо прочего, это «дорогая педагогика»: она доступна только педагогам с высокой квалификацией, обученным не на потоке и активно занимающимся самообразованием (таких меньшинство); ее практическое применение также требует больших организационно-административных затрат, чем «обычно»; 